\title{
Canada's perceived lack of leadership on global tobacco control
}

Previously published at www.cmaj.ca

$\mathrm{T}$ he International Development Research Centre (IDRC), Canada's leading institution of innovation and research in global health, recently revealed that the Chair of its Board, Barbara McDougall, was also a tobacco industry executive from 2004 until April 2010, stepping down only after African nongovernmental organizations pointed out the conflict. Given her role on the Board of Imperial Tobacco, one can only conclude that tobacco control will no longer be a priority for IDRC and the Government of Canada.

Ms. McDougall, a former Conservative Cabinet minister, was appointed to the Board of IDRC by the Prime Minister; her appointment was vetted and approved by both the Privy Council Office and the Prime Minister's Office. Her nomination would have been supported by the Minister of Foreign Affairs, to whom IDRC reports, and the President of IDRC. Although it is not clear why such marked conflicts were not detected and disclosed earlier, it is clear that Ms. McDougall's recent resignation from Imperial Tobacco's Board does not sufficiently remove these conflicts.

In her role as a member of Imperial Tobacco's Board, Ms. McDougall would have seen, discussed and possibly approved major marketing campaigns designed to develop foreign markets. Although legal, supporting tobacco marketing in emerging markets is diametrically opposite to the stated mission of IDRC - to reduce poverty in developing countries through science and knowledge.

This is especially worrisome because the stakes are enormous. Tobacco use kills over five million people every year, and rates of death are increasing most in developing countries. ${ }^{1}$ Unless there is widespread cessation, tobacco use will kill about one billion people in this century, primarily in developing countries.

These deaths not only affect the poor countries, but also the poorest within them. In India, half of the one million annual deaths from smoking occur among the illiterate. Smoking triples the risk of tuberculosis. ${ }^{3}$ Smoking accounts for over half the disparity in rates of death between rich and poor men. ${ }^{4}$ Although rates of smokingrelated death have fallen sharply in men in high-income countries, they continue to rise in developing countries.

Imperial Tobacco, and its parent company, British American Tobacco, continue to target the same developing countries that IDRC seeks to serve. Imperial Tobacco narrowly escaped criminal conviction and paid hefty fines for its role in abetting smuggling of cigarettes into Canada in the 1990s. Evidence from the Canadian case is used by "Big Tobacco" to deter developing countries from raising taxes on tobacco products. ${ }^{5}$ Efforts by the tobacco industry to distort the poverty agenda of various agencies, including the World Bank and WHO, are well-documented.

Ms. McDougall's ongoing role on IDRC's Board has undermined the institution's reputation and her effectiveness as Chair. Soon after her role with Imperial Tobacco became widely known, the Gates Foundation immediately cancelled a multi-million dollar grant to IDRC to develop tobacco control strategies in Africa. IDRC's agenda to advance better governance, including in health, now raises concerns about double standards. IDRC staff are no longer invited to some technical meetings. Protest letters from around the world continue. Whether real or perceived, other international stakeholders have judged IDRC's actions, and the verdict is harsh.

Years of hard work by the Government of Canada are under threat. IDRC showed early leadership by linking tobacco to economic development in its 1995 Bellagio Statement on tobacco. ${ }^{7}$ Canada made important contributions to WHO's Framework Convention on Tobacco Control, a first-ever global treaty in public health. ${ }^{8}$

There is simply no place for the tobacco industry on the development and poverty agenda. The Framework Convention on Tobacco Control prohibits direct funding or involvement from the tobacco industry in research or any other development activities; its guiding principles call for protection of government policy-making from tobacco industry influence. This includes IDRC, which reports to Parliament and is funded mostly by Canadian taxpayers. Forbidding any form of involvement with Big Tobacco is common practice in health research and dissemination through medical journals such as CMAJ. Given that millions of lives in developing countries are at risk, no less a rigorous standard is warranted.

Ms. McDougall, who has had a distinguished record of public service, would best serve IDRC by stepping aside. Lawrence Cannon, Minister of Foreign Affairs, and David Malone, IDRC's new and capable President, should accept her resignation. Others, such as The Globe and Mail, ${ }^{9}$ have suggested that simply speaking out on the harms of tobacco will suffice. Indeed, IDRC should ask its stakeholders if anything short of a resignation will reaffirm IDRC and Canada's commitment to global tobacco control and global health on the heels of the G20 summit.

\section{Paul C. Hébert MD MHSc}

Editor-in-Chief, $C M A J$

\section{K. Srinath Reddy MBBS MD}

President, Public Health Foundation of India

New Delhi, India

Prabhat Jha MD DPhil

Director, Centre for Global Health Research

St. Michael's Hospital, University of Toronto

Toronto, Ont

With the editorial advisory team: Matthew B. Stanbrook MD PhD, Ken Flegel MDCM MSc and Noni MacDonald MD MSc

Competing interests: See www.cmaj.ca/misc/edboard.shtml for editorial advisory team statements. None declared for K. Srinath Reddy and Prabhat Jha.

CMAJ 2010. DOI:10.1503/cmaj.100850

\section{REFERENCES}

1. Jha P. Avoidance of worldwide cancer mortality and total mortality from smoking Nat Rev Cancer 2009;9:655-64.

2. Peto R, Lopez AD, Boreham J, et al. Mortality from tobacco in developed coun tries. Oxford (UK): Oxford University Press, 1994.

3. Jha P, Jacob B, Gajalakshmi V, et al. A nationally representative case-contro study of smoking and death in India. N Engl J Med 2008;358:1137-47.

4. Jha P, Peto R, Zatonski W, et al. Social inequalities in male mortality, and in male mortality from smoking: indirect estimation from national death rates in England and Wales, Poland, and North America. Lancet 2006;368:367-70.

5. LeGresley E, Lee K, Muggli ME et al. British American Tobacco and the "insidious impact of illicit trade" in cigarettes across Africa. Tob Control 2008;17:339-46.

6. Mamudu HM, Hammond R, Glantz S. Tobacco industry attempts to counter the World Bank report Curbing the Epidemic and obstruct the WHO framework convention on tobacco control. Soc Sci Med 2008;67:1690-9.

7. De Savigny D. IDRC Bellagio Statement on tobacco and sustainable development CMAJ 1995;153:1109-10. Available: www.ncbi.nlm.nih.gov/pmc/articles /PMC1487336/pdf/cmaj00080-0059.pdf (accessed 2010 June 18).

8. Lavack AM, Clark G. Responding to the global tobacco industry: Canada and the Framework Convention on Tobacco Control. Can Public Adm 2007:50:100-18.

9. Blowing smoke over Ms. McDougall. Globe and Mail [Toronto] 2010 June 19; Sect. A:20. 